\title{
Mentorship of Women in Academic Medicine: a Systematic Review
}

\author{
Amy H. Farkas, $M D, M S^{1,2}$, Eliana Bonifacino, MD, $M S^{3}$, Rose Turner, MLIS', \\ Sarah A. Tilstra, MD, $M S^{3}$, and Jennifer A. Corbelli, MD, $M S^{3}$ \\ 'Division of General Internal Medicine, Medical College of Wisconsin, Milwaukee, WI, USA; ${ }^{2}$ Milwaukee VA Medical Center, Milwaukee, WI, USA; \\ ${ }^{3}$ Division of General Internal Medicine, University of Pittsburgh School of Medicine, Pittsburgh, PA, USA; ${ }^{4}$ Falk Library of the Health Sciences, University \\ of Pittsburgh, Pittsburgh, PA, USA.
}

BACKGROUND: Women remain underrepresented in academic medicine, particularly in leadership positions. This lack of women in leadership has been shown to have negative implications for both patient care and educational outcomes. Similarly, the literature demonstrates that female physicians are less likely to have mentors, despite the proven benefits of mentorship for career advancement. The objective of this review is to identify and describe models of mentorship for women in academic medicine.

METHODS: We searched PubMed, PsycINFO, Education Resources Information Center, and Cochrane Databases of Systematic Reviews following PRISMA guidelines in June 2017. We included original English language studies that described a mentorship program in the USA that involved academic medical doctorates and that were created for women or provided results stratified by gender.

RESULTS: Our search returned 3625 results; 3309 references remained after removal of duplicates. Twenty articles met inclusion criteria. The majority of the programs were designed for junior faculty and used the dyad model of mentoring (i.e., one mentor/one mentee). Frequently cited objectives of these programs were to improve scholarship, promotion, and retention of female faculty. Program evaluations were primarily survey-based, with participant-reported satisfaction being the most frequent measured outcome. Most results showed very high satisfaction. Gender concordance between mentor and mentee did not impact satisfaction. Eight articles reported objective outcomes, including publications, retention, and promotion, and each of these demonstrated an improvement after program implementation.

DISCUSSION: Our review suggests that mentorship programs designed for women, regardless of the model, are met with high satisfaction and can help promote and retain women in academic medicine. No clear best practices for mentorship emerged in the literature. Institutions, therefore, can individualize their mentorship programs and models to available resources and goals. These results demonstrate the importance of more widespread implementation of mentorship programs to more effectively facilitate professional development and success of women in academic medicine.

Published online April 29, 2019
KEY WORDS: mentoring; women; academic medicine.

$\mathrm{J}$ Gen Intern Med 34(7):1322-9

DOI: $10.1007 / \mathrm{s} 11606-019-04955-2$

(c) Society of General Internal Medicine (This is a U.S. government work and not under copyright protection in the U.S.; foreign copyright protection may apply) 2019

\section{INTRODUCTION}

Women have accounted for approximately $50 \%$ of medical school matriculants since 2003; however, they remain underrepresented in academic medicine, representing only $39 \%$ of full-time faculty. Even fewer women attain leadership roles, with women representing only $22 \%$ of full professors, $16 \%$ of department chairs, and $17 \%$ of medical school deans. ${ }^{1}$ This phenomenon has been referred to as the "leaky pipeline" of academic medicine. Female physicians are more likely to leave academic medicine, fail to reach leadership positions, and be undercompensated. Specifically, women full and associate professors are paid at the level of male associate and assistant professors, respectively. ${ }^{2}$ Inequity in promotion and compensation is described in a recent Journal of General Internal Medicine editorial as key components of systemic gender-based bias in academic medicine. ${ }^{3}$ Mentorship has been proposed as one important method to address gender disparities and bias.

Previous work has demonstrated that mentorship is associated with increased career satisfaction, faculty retention, productivity, and promotion of medical faculty. ${ }^{4}$ Despite these benefits, women are less likely to have a mentor compared to the male colleagues across varying levels of training. ${ }^{5}$ Additionally, female physicians and professional organizations have identified the lack of mentorship as a significant impediment to career development. ${ }^{6-9}$ This may be, in part, due to the paucity of women in senior positions. This paradigm limits the mentor pool for junior faculty and trainees, as traditional mentorship tends to evolve spontaneously from shared experiences, challenges, and interests.

To increase the number and quality of mentorship opportunities for women, some institutions have implemented formal mentorship programs for their female faculty. The purpose of this review is to identify and describe models of mentorship for women in 
academic medicine, and as much as possible within the limitations of the literature, to outline the respective benefits and limitations of these programs.

\section{METHODS}

\section{Search Strategy and Study Selection}

We searched PubMed including Medline (1966-present), PsycINFO (1597-present), the Education Resources Information Center (ERIC) (1966-present), and the Cochrane Database of Systematic Reviews (1992-present) following the Preferred Reporting Items for Systematic Reviews and Meta-Analyses (PRISMA) guidelines ${ }^{10}$ in order to identify studies that describe mentorship programs for women. Search strategies (Appendix) were developed through collaboration with a health sciences librarian (RT). Using each database platform's subject headings and search fields, various combinations of the following subject headings and keyword groupings were investigated: mentoring, academic medicine, physicians (see Appendix for full search strategy). Searches were finalized on June 22, 2017. Two reviewers $(\mathrm{EB}$ and $\mathrm{AF})$ independently evaluated all records for eligibility using DistillerSR, a Web-based systematic review data management system. Any discrepancies regarding inclusions were resolved by group consensus and consultation with the senior author (JC).

\section{Study Eligibility Criteria}

We included original, English language published studies that met the following inclusion criteria: (1) Described a mentorship program, exclusive of mentoring for a specific/procedural skill; (2) Involved academic medical doctorates at the faculty or trainee level (medical students, residents, or fellows); (3) Described a program designed for women or provided results stratified by gender; and (4) Described a program conducted in the USA. Full inclusion and exclusion criteria are described in our protocol registered on PROSPERO and can be accessed at https://www.crd.york.ac.uk/PROSPERO/display_record. asp?ID=CRD42017067913. For this review, we defined mentorship as previously defined in the literature, "a developmental partnership in which knowledge, experience, skills, and information are shared between mentor(s) and mentee(s) to foster the mentee's professional development and, often, also to enhance the mentor's perspectives and knowledge." 11

\section{Data Abstraction}

Two study authors (EB and AF) independently abstracted all data. Study abstraction forms consisted of fields including the following: (1) the author and year the study was published; (2) the number of participants and academic level; (3) gender of mentor/mentee; (4) program design specific for women; (5) model of mentorship (i.e., dyadic, peer mentoring); (6) program objectives; (7) description of program components; (8) program evaluation including whether the program was evaluated, and methods of evaluation; (9) results of evaluation; and (10) program cost.

\section{Quality Assessment}

A formal quality assessment of manuscripts was precluded, as neither the Cochrane Risk of Bias nor the Newcastle Ottawa Scale can be applied to the only type of study (descriptive) that exists in the mentorship literature.

\section{RESULTS}

\section{Study Selection}

We retrieved 3625 total citations in PubMed, ERIC, PsycINFO, and the Cochrane Database of Systematic Reviews in June 2017. After screening for duplicate records, 3308 remained. An additional reference, which had yet to be indexed in PubMed, was identified outside of the search for a total of 3309 references. A total of 2577 records were excluded based on title and abstract screening, and 732 underwent full-text review (Fig. 1). Twenty studies met all of our inclusion criteria and were included in our review. These 20 studies described 19 separate mentorship programs. One article described two separate programs at two different institutions. ${ }^{12}$ Three articles reported results from the same program in pilot form, ${ }^{13}$ an expanded program, ${ }^{14}$ and with longterm outcome data demonstrating objective outcomes in all three phases of the program. ${ }^{15}$ The results of these articles are presented and listed in Table 1.

\section{Program Description}

Twelve of the 19 programs were designed for junior faculty, as defined by individual study authors. ${ }^{12-24}$ While most of the included programs were exclusively for medical doctorates, one program for junior faculty was interdisciplinary and included female psychologists and social workers. ${ }^{17}$ Four programs included physicians across a range of levels $\mathrm{s}^{25-28}$ and three of the programs included only those at the trainee level: two for medical students ${ }^{29,} 30$ and one for residents. ${ }^{31}$ Fifteen of the programs were specifically developed for female physicians, ${ }^{12-15,17-21,24-31}$ and ten programs used exclusively female faculty as the mentors. ${ }^{12-15,18,20,24,26-31}$ In five of the programs, the gender of the mentors was unclear ${ }^{16-18,22,23,25}$ and the remaining programs included both male and female mentors. ${ }^{12,19,21}$ Ten of the programs described larger institutional professional development initiatives for women for which mentorship was a component of the initiative. ${ }^{12,16,17}$, 20, 25-28, 30, 31 Commonly described components of these larger programs included workshops for participants, development of electronic resources, classes for skills development, networking events, guest speakers, and journal and/or book club discussions. 


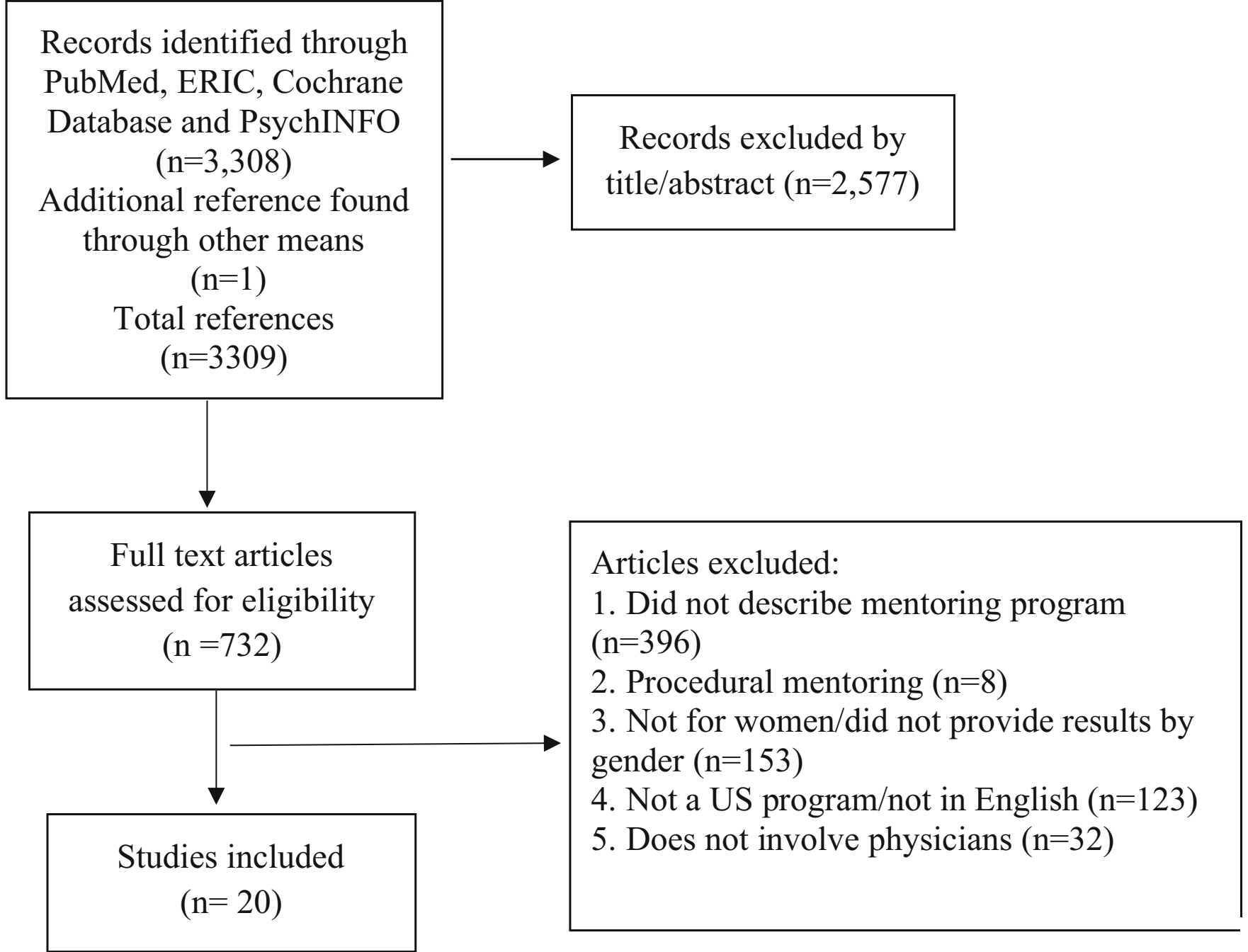

Figure 1 PRISMA diagram.

\section{Mentoring Models}

The most commonly cited model of mentorship was the traditional dyad model (i.e., one mentor/one mentee), which was used by ten of the programs. ${ }^{12,16,19-23,27,29}$ Peer and facilitated peer mentoring was the next most commonly cited model, used in four of the programs. ${ }^{13-15,17,18,24}$ Group mentorship was used in two of the programs, ${ }^{28,} 30$ and for the remaining programs, the mentorship model was not clearly

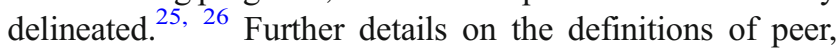
facilitated peer, and group mentorship have all been previously described in the literature. ${ }^{32}$

\section{Program Objectives}

While many of the programs described broad objectives related to career development, faculty development, or mentorship and guidance, several of the programs had more specific objectives aimed at faculty recruitment, retention, promotion, and scholarship. Four of the 20 programs specifically aimed to increase the number of women within the specialty or department: two programs were intended to recruit female medical students into specific specialties (surgery and diagnostic radiology) ${ }^{27,29}$ and two were designed for female faculty in specific departments (ENT and psychiatry). ${ }^{17,}{ }^{26} \mathrm{Six}$ of the programs set objectives related to the promotion of female faculty. ${ }^{12,16,20,21,25}$ Three programs were focused on improving scholarship ${ }^{13-16,18,22}$ with two additional ones aimed at improving specific skills important to a career in academic medicine, such as public speaking or teaching. ${ }^{27,31}$

\section{Program Evaluation}

The majority of the programs' primary outcome was participant satisfaction with the program, as measured by surveys. The programs were consistently highly rated by the participants. Among the $14 / 20$ programs that reported on gender concordance between mentors and mentees, no differences emerged among programs for which all mentors were female and programs for which male mentors were included.

Eight articles provided objective outcomes for their programs, citing increased recruitment, retention, or promotion of female faculty or publication of scholarship. ${ }^{13-17,25-27}$ One program reported an $85 \%$ retention rate for the female faculty who participated in the program which was higher than the 
Table 1 Description of Mentorship Programs for Women in Academic Medicine

\begin{tabular}{|c|c|c|c|c|c|c|}
\hline $\begin{array}{l}\text { Study } \\
\text { (year) }\end{array}$ & $\begin{array}{l}\text { Program } \\
\text { description* }\end{array}$ & $\begin{array}{l}\text { Mentorship } \\
\text { model }\end{array}$ & Program objectives & Program components & $\begin{array}{l}\text { Program } \\
\text { evaluation }\end{array}$ & Evaluation results \\
\hline $\begin{array}{l}\text { Wingard } \\
\text { (2004) }\end{array}$ & $\begin{array}{l}67 \text { junior faculty } \\
(56 \mathrm{MDs}) \text { of whom } \\
37 \text { were women } \\
\text { with mixed gender } \\
\text { mentors }\end{array}$ & Dyad & $\begin{array}{l}\text { Provide feedback } \\
\text { about academic } \\
\text { progress, enhance } \\
\text { connection to the } \\
\text { school of medicine, } \\
\text { increase sense of } \\
\text { community }\end{array}$ & $\begin{array}{l}\text { Weekly half-day work- } \\
\text { shops, regular meetings } \\
\text { with mentor, completion } \\
\text { of a professional devel- } \\
\text { opment project }\end{array}$ & $\begin{array}{l}\text { Survey and } \\
\text { faculty } \\
\text { retention }\end{array}$ & $\begin{array}{l}84 \% \text { retention rate for } \\
\text { the women who } \\
\text { participated } \\
\text { Participants were } \\
\text { significantly more } \\
\text { confident in academic } \\
\text { roles and skills }\end{array}$ \\
\hline $\begin{array}{l}\text { Seritan } \\
(2007)\end{array}$ & $\begin{array}{l}\text { Female junior } \\
\text { faculty (MDs, } \\
\text { psychologist, and } \\
\text { social workers) } \\
\text { with mentors of } \\
\text { unclear gender }\end{array}$ & Peer & $\begin{array}{l}\text { Foster faculty } \\
\text { development, peer } \\
\text { support, and mentoring } \\
\text { for recruitment and } \\
\text { retention of female } \\
\text { faculty }\end{array}$ & $\begin{array}{l}\text { Development of a } \\
\text { website for the program } \\
\text { Month/every other } \\
\text { month meetings, } \\
\text { mentoring as needed, } \\
\text { special events, and } \\
\text { faculty development } \\
\text { programs }\end{array}$ & Survey & $\begin{array}{l}\text { Within a year, the } \\
\text { number of female } \\
\text { faculty increased from } \\
22 \text { to } 26 \text { (29\% to } 33 \%) \\
\text { Participants reported a } \\
\text { sense of community } \\
\text { and improved } \\
\text { relationships with } \\
\text { other female faculty }\end{array}$ \\
\hline $\begin{array}{l}\text { Files } \\
(2008)\end{array}$ & $\begin{array}{l}4 \text { female junior } \\
\text { faculty MDs (pilot) } \\
\text { with female men- } \\
\text { tors }\end{array}$ & $\begin{array}{l}\text { Facilitated } \\
\text { peer }\end{array}$ & $\begin{array}{l}\text { Improve academic } \\
\text { productivity }\end{array}$ & $\begin{array}{l}\text { Mentees are divided } \\
\text { into peer small groups } \\
\text { with an assigned senior } \\
\text { mentor. Groups work }\end{array}$ & Survey & $\begin{array}{l}\text { (1) } 3 \text { of the } 4 \text { peers co- } \\
\text { authored a manuscript } \\
\text { and were promoted } \\
\text { (2) At } 12 \text { months, } 9\end{array}$ \\
\hline $\begin{array}{l}\text { Varkey } \\
(2012)\end{array}$ & $\begin{array}{l}19 \text { female junior } \\
\text { faculty (17 MDs) } \\
\text { (expanded } \\
\text { program) with } \\
\text { female mentors }\end{array}$ & & & $\begin{array}{l}\text { toward the completion } \\
\text { of a manuscript for } \\
\text { publication }\end{array}$ & & $\begin{array}{l}\text { manuscripts were } \\
\text { submitted } \\
\text { Participants reported } \\
\text { an increase in } \\
\text { satisfaction and skills }\end{array}$ \\
\hline $\begin{array}{l}\text { Mayer } \\
(2014)\end{array}$ & $\begin{array}{l}33 \text { female junior } \\
\text { faculty MDs (long- } \\
\text { term follow-up) } \\
\text { Data from } 16 \\
\text { faculty members } \\
\text { with female } \\
\text { mentors }\end{array}$ & & & & & $\begin{array}{l}\text { (3) } 6 \text { of the } 16 \text { faculty } \\
\text { received a promotion; } \\
44 \% \text { continue to work } \\
\text { with their peer group }\end{array}$ \\
\hline $\begin{array}{l}\text { Bauman } \\
(2014)\end{array}$ & $\begin{array}{l}\text { Female faculty and } \\
\text { medical students } \\
\text { with mentors of } \\
\text { unclear gender }\end{array}$ & Unclear & $\begin{array}{l}\text { Create a pool of future } \\
\text { female leaders }\end{array}$ & $\begin{array}{l}\text { 1-2-year mentored } \\
\text { leadership development } \\
\text { opportunity for early- } \\
\text { career faculty member } \\
\text { Also included was } \\
\text { annual drop-in } \\
\text { mentoring clinic for } \\
\text { faculty. Mentorship of } \\
\text { students interested in } \\
\text { careers in academic } \\
\text { medicine through } \\
\text { classes, workshops, and } \\
\text { other events }\end{array}$ & $\begin{array}{l}\text { Promotion and } \\
\text { retention data }\end{array}$ & $\begin{array}{l}\text { Improvement in the } \\
\text { number of female } \\
\text { faculty from } 139 \text { to } \\
235 \text { and improvement } \\
\text { in the number of } \\
\text { female department } \\
\text { chairs from } 1 \text { to } 5 \\
\text { Compared to national } \\
\text { data, departure rate at } \\
\text { the school of medicine } \\
\text { is lower than the } \\
\text { national average ( } 34 \% \\
\text { vs. } 40 \% \text { ) }\end{array}$ \\
\hline Lin (2016) & $\begin{array}{l}\text { Female faculty, } \\
\text { fellows, residents } \\
\text { with female } \\
\text { mentors }\end{array}$ & Unclear & $\begin{array}{l}\text { Increase diversity } \\
\text { within the ENT } \\
\text { department }\end{array}$ & $\begin{array}{l}\text { Mentorship offered as } \\
\text { part of a larger initiative, } \\
\text { opportunities for } \\
\text { women to discuss } \\
\text { practical approaches to } \\
\text { work-life balance, net- } \\
\text { working opportunities, } \\
\text { and strategies for pro- } \\
\text { fessional advancement }\end{array}$ & $\begin{array}{l}\text { Evaluated } \\
\text { academic } \\
\text { rank, } \\
\text { leadership } \\
\text { positions, and } \\
\text { salary }\end{array}$ & $\begin{array}{l}\text { Increased the number } \\
\text { of women at associate } \\
\text { level from } 0 \text { to } 6 \\
\text { Increased leadership } \\
\text { positions held by } \\
\text { women } 0 \text { to } 5\end{array}$ \\
\hline $\begin{array}{l}\text { Ladd } \\
(2017)\end{array}$ & $\begin{array}{l}\text { Female faculty, } \\
\text { residents, medical } \\
\text { students with } \\
\text { female mentors }\end{array}$ & Dyad & $\begin{array}{l}\text { Provide mentorship } \\
\text { and networking } \\
\text { resources, to enable the } \\
\text { development of skills } \\
\text { needed for success, to } \\
\text { improve the gender } \\
\text { gap in radiology }\end{array}$ & $\begin{array}{l}\text { Paired mentoring of } \\
\text { trainees with faculty, } \\
\text { regular meetings } \\
\text { focusing on guest } \\
\text { speakers, journal clubs, } \\
\text { fellowship/job fairs, and } \\
\text { medical student out- } \\
\text { reach }\end{array}$ & Survey & $\begin{array}{l}30 \% \text { increase in the } \\
\text { number of female } \\
\text { medical students going } \\
\text { into diagnostic } \\
\text { radiology (13 from 10) } \\
90 \% \text { agreed that the } \\
\text { group provided a } \\
\text { networking platform }\end{array}$ \\
\hline $\begin{array}{l}\text { Illes } \\
(2000)\end{array}$ & $\begin{array}{l}23 \text { junior faculty, } 8 \\
\text { were women with } \\
\text { mixed gender } \\
\text { mentors }\end{array}$ & Dyad & $\begin{array}{l}\text { Promote the career } \\
\text { development of junior } \\
\text { faculty }\end{array}$ & $\begin{array}{l}\text { Semiannual mentoring } \\
\text { meetings }\end{array}$ & Survey & $\begin{array}{l}\text { Female faculty on } \\
\text { average over } 5 \\
\text { evaluations rated the } \\
\text { program as extremely } \\
\text { important }(9.15 / 10)\end{array}$ \\
\hline
\end{tabular}


Table 1. (continued)

\begin{tabular}{|c|c|c|c|c|c|c|}
\hline $\begin{array}{l}\text { Study } \\
\text { (year) }\end{array}$ & $\begin{array}{l}\text { Program } \\
\text { description* }\end{array}$ & $\begin{array}{l}\text { Mentorship } \\
\text { model }\end{array}$ & Program objectives & Program components & $\begin{array}{l}\text { Program } \\
\text { evaluation }\end{array}$ & Evaluation results \\
\hline & $\begin{array}{l}49 \text { female junior } \\
\text { faculty ( } 34 \text { MDs) } \\
\text { with mentors of } \\
\text { mixed gender }\end{array}$ & & $\begin{array}{l}\text { Promoting the } \\
\text { professional } \\
\text { development and } \\
\text { career advancement of } \\
\text { women }\end{array}$ & $\begin{array}{l}\text { Mentoring meetings as } \\
\text { per the discretion of the } \\
\text { mentoring pairs; other } \\
\text { initiatives included book } \\
\text { discussions, guest } \\
\text { lectures, and lunches }\end{array}$ & $\begin{array}{l}\text { Qualitative } \\
\text { evaluation }\end{array}$ & $\begin{array}{l}\text { Program participants } \\
\text { were very satisfied } \\
\text { with their relationships }\end{array}$ \\
\hline $\begin{array}{l}\text { Von Feldt } \\
(2009)\end{array}$ & $\begin{array}{l}93 \text { female assistant } \\
\text { professors with } \\
\text { female mentors }\end{array}$ & Dyad (speed) & $\begin{array}{l}\text { Ensure that faculty are } \\
\text { on the path to } \\
\text { promotion }\end{array}$ & $\begin{array}{l}\text { 30-min CV review } \\
\text { session offered during } \\
\text { an annual professional } \\
\text { development conference } \\
\text { for women }\end{array}$ & Survey & $\begin{array}{l}93 \% \text { found the CV } \\
\text { review session helpful, } \\
\text { and } 89 \% \text { said they } \\
\text { would participate in a } \\
\text { session like this again }\end{array}$ \\
\hline $\begin{array}{l}\text { Butch } \\
(2009)\end{array}$ & $\begin{array}{l}\text { Female assistant } \\
\text { professor surgeons } \\
\text { with mixed gender } \\
\text { mentors }\end{array}$ & Dyad & $\begin{array}{l}\text { Assist with promotion } \\
\text { and other career goals }\end{array}$ & No formal program & None & NA \\
\hline $\begin{array}{l}\text { Mayer } \\
(2009)\end{array}$ & $\begin{array}{l}3 \text { female junior } \\
\text { faculty, all MDs } \\
\text { with mentors of } \\
\text { unclear gender }\end{array}$ & $\begin{array}{l}\text { Facilitated } \\
\text { peer }\end{array}$ & $\begin{array}{l}\text { Complete a scientific } \\
\text { writing project }\end{array}$ & $\begin{array}{l}\text { Mentors provided a } \\
\text { work environment with } \\
\text { childcare and food to } \\
\text { allow the junior mentees } \\
\text { to complete their writing } \\
\text { task }\end{array}$ & None & $\begin{array}{l}\text { Report that the peer } \\
\text { group has remained } \\
\text { together and } \\
\text { completed additional } \\
\text { academic projects }\end{array}$ \\
\hline $\begin{array}{l}\text { Welch } \\
(2012)\end{array}$ & $\begin{array}{l}72 \text { female faculty } \\
\text { and residents in } \\
\text { emergency } \\
\text { medicine with } \\
\text { female mentors }\end{array}$ & Group & $\begin{array}{l}\text { Provide mentors and } \\
\text { role models for } \\
\text { inspiration and } \\
\text { guidance }\end{array}$ & $\begin{array}{l}\text { Scheduled group } \\
\text { mentoring sessions } \\
\text { under the direction of a } \\
\text { female faculty member } \\
\text { Structured 2-h sessions } \\
\text { every other month } \\
\text { Also included 4-h well- } \\
\text { ness workshops and an- } \\
\text { nual state-wide } \\
\text { breakfast with national } \\
\text { female emergency med- } \\
\text { icine leader }\end{array}$ & Survey & $\begin{array}{l}87 \% \text { reported the } \\
\text { program provided } \\
\text { mentors and role } \\
\text { models } \\
60 \% \text { reported } \\
\text { benefitting from a peer } \\
\text { mentoring relationship }\end{array}$ \\
\hline $\begin{array}{l}\text { Levy } \\
(2013)\end{array}$ & $\begin{array}{l}75 \text { young } \\
\text { investigators, both } \\
\text { men and women } \\
\text { with mentors of } \\
\text { unclear gender }\end{array}$ & Dyad & $\begin{array}{l}\text { Provide support and } \\
\text { guidance for } \\
\text { collaboration and } \\
\text { facilitate interactions } \\
\text { of young investigators }\end{array}$ & $\begin{array}{l}\text { 3-year mentor/mentee } \\
\text { pairing }\end{array}$ & Survey & $\begin{array}{l}\text { Majority of } \\
\text { participants were } \\
\text { satisfied with the } \\
\text { program } \\
\text { No difference in } \\
\text { academic productivity } \\
\text { between genders }\end{array}$ \\
\hline $\begin{array}{l}\text { Blood } \\
(2015)\end{array}$ & $\begin{array}{l}10 \text { female fellows/ } \\
\text { junior faculty ( } 8 \\
\text { MDs) with mentors } \\
\text { of unclear gender }\end{array}$ & $\begin{array}{l}\text { Dyad } \\
\text { distance }\end{array}$ & $\begin{array}{l}\text { Provide an opportunity } \\
\text { for group-based men- } \\
\text { torship sessions and } \\
\text { individual distance } \\
\text { mentoring }\end{array}$ & $\begin{array}{l}\text { Mentoring forum at a } \\
\text { national meeting, } \\
\text { distance } 1 \text {-on-1 } \\
\text { mentoring }\end{array}$ & Survey & $\begin{array}{l}\text { At 1-year follow-up, } 5 \\
\text { out of } 6 \text { indicated they } \\
\text { were "very satisfied" } \\
\text { with mentor match, } \\
\text { and } 4 \text { planned to con- } \\
\text { tinue with their mentor }\end{array}$ \\
\hline $\begin{array}{l}\text { Bhatia } \\
(2015)\end{array}$ & $\begin{array}{l}24 \text { female } \\
\text { emergency } \\
\text { medicine residents } \\
\text { with female } \\
\text { mentors }\end{array}$ & Group & $\begin{array}{l}\text { Provide role modeling, } \\
\text { mentorship, and } \\
\text { education in critical } \\
\text { skills required to } \\
\text { succeed }\end{array}$ & $\begin{array}{l}\text { Mentorship events } \\
\text { hosted by faculty with a } \\
\text { predetermined } \\
\text { discussion theme, online } \\
\text { repository of resources, } \\
\text { roundtable discussions }\end{array}$ & Survey & $\begin{array}{l}81.8 \% \text { of senior } \\
\text { residents said the } \\
\text { events provided them } \\
\text { with mentorship } \\
76.4 \% \text { reported that } \\
\text { the events provided } \\
\text { skills and insight to } \\
\text { better inform their } \\
\text { practice choice and } \\
\text { prepare them for } \\
\text { academics }\end{array}$ \\
\hline $\begin{array}{l}\text { Khan } \\
(2016)\end{array}$ & $\begin{array}{l}5 \text { female medical } \\
\text { students with } \\
\text { female mentors }\end{array}$ & Dyad & $\begin{array}{l}\text { Improve recruitment of } \\
\text { female medical } \\
\text { students to surgical } \\
\text { careers }\end{array}$ & $\begin{array}{l}3 \text { meetings per year and } \\
\text { students shadowed their } \\
\text { mentor in clinical duties }\end{array}$ & $\begin{array}{l}\text { Qualitative } \\
\text { evaluation }\end{array}$ & $\begin{array}{l}80 \% \text { of students } \\
\text { reported that female } \\
\text { surgeons had a } \\
\text { manageable lifestyle, } \\
80 \% \text { got involved with } \\
\text { research, and } 80 \% \\
\text { gained clinical } \\
\text { exposure }\end{array}$ \\
\hline $\begin{array}{l}\text { Defillipis } \\
\text { (2016) }\end{array}$ & $\begin{array}{l}58 \text { female medical } \\
\text { students with } \\
\text { female mentors }\end{array}$ & Group & $\begin{array}{l}\text { To improve } \\
\text { mentorship } \\
\text { opportunities for } \\
\text { female medical } \\
\text { students }\end{array}$ & $\begin{array}{l}3 \text { major events were } \\
\text { held throughout the year } \\
\text { that included } \\
\text { discussions on work-life } \\
\text { balance, salary negotia- } \\
\text { tion, and gender in the } \\
\text { workplace. Individual }\end{array}$ & Survey & $\begin{array}{l}77 \% \text { felt strongly that } \\
\text { the program provided } \\
\text { opportunities for } \\
\text { mentoring, and } 82 \% \\
\text { felt the program filled } \\
\text { an institutional need }\end{array}$ \\
\hline
\end{tabular}


Table 1. (continued)

\begin{tabular}{|c|c|c|c|c|c|c|}
\hline $\begin{array}{l}\text { Study } \\
\text { (year) }\end{array}$ & $\begin{array}{l}\text { Program } \\
\text { description* }\end{array}$ & $\begin{array}{l}\text { Mentorship } \\
\text { model }\end{array}$ & Program objectives & Program components & $\begin{array}{l}\text { Program } \\
\text { evaluation }\end{array}$ & Evaluation results \\
\hline $\begin{array}{l}\text { Erlich } \\
\text { (2017) }\end{array}$ & $\begin{array}{l}3 \text { female junior } \\
\text { faculty, all MDs } \\
\text { with female } \\
\text { mentors }\end{array}$ & Peer & $\begin{array}{l}\text { To meet the } \\
\text { professional } \\
\text { development needs of } \\
\text { participants and to } \\
\text { offer peer support } \\
\text { during professional } \\
\text { transition and growth }\end{array}$ & $\begin{array}{l}\text { groups were encouraged } \\
\text { to meet periodically } \\
\text { Peer mentoring } \\
\text { meetings occurring } \\
\text { every 1-2 months based } \\
\text { on member's needs }\end{array}$ & None & NA \\
\hline
\end{tabular}

NA not available CV curriculum vitae

*When provided in the paper, we have listed the total number of participants, type of participants including the number of MDs, and the number of women participants; if not listed, this information was not provided by the paper

national average. ${ }^{16}$ Another program reported improvement in the number of female faculty and female department chairs, as well as improvement in retention with a departure rate of women from the school of medicine of $34 \%$, compared to a national average of $40 \% .^{25}$ Regarding the papers that described the same program in three phases, for both the pilot and expanded programs, the studies reported on submitted manuscripts as an outcome. ${ }^{13-15}$ The paper describing longterm data reported on faculty promotion based on retrospective CV review, finding that 6 of the 16 faculty received a promotion up to 5 years after enrollment. Two other programs reported improvement in recruitment of women into the department or the specialty. ${ }^{17,27}$

\section{Program Cost}

Few articles described the cost of the programs. Only one article provided a cost breakdown which showed that their program, which involved significant faculty time for attending weekly half-day workshops and cost $\$ 670,000$ over 4 years including salary support for faculty members' time to participate. ${ }^{16}$ However, they reported that given the improvement in the retention rate of their female faculty, the program produced a cost savings of $\$ 330,000$ over 4 years. One program reported that their mentorship program was provided with financial support from the deans' office of approximately $\$ 30,000$ per year. $^{12}$ Another program reported a small budget of $\$ 2500$ provided by the residency office. ${ }^{27}$ An additional program did not report specific cost in terms of faculty time but reported that each peer mentee was provided with $25 \mathrm{~h}$ of protected time for which to attend the program. ${ }^{13}$

\section{Limitations or Barriers of Programs}

Very few of the articles discussed barriers of the mentorship programs; however, several limitations are evident. In general, the sample size was small, ranging from $4^{13}$ to $93^{20}$ participants and none of the programs had a control group, which creates a concern for selection bias as those who chose to participate in a mentorship program likely differ from faculty that choose not to participate. Furthermore, a lack of a control group also limits the ability to draw definitive conclusions about the impact of a specific mentorship program, as other institutional initiatives may have occurred simultaneously that could have influenced results of these manuscripts. Additionally, the short-term follow-up, subjective outcome measures, and unclear response rates in many of the papers limit the ability to evaluate both the immediate and, importantly, the sustained impacts of these programs. Finally, some of the authors commented that, occasionally, the matched mentoring pairs did not result in ideal pairings, thus limiting the effectiveness of the intervention for some participants. ${ }^{22,30}$

Among those programs that cited specific barriers, one cited a lack of support staff as a barrier to the success of the program. ${ }^{12}$ Two cited time as a limitation for both the mentor ${ }^{19}$ and mentees, ${ }^{24}$ and it is likely that all mentorship programs face this barrier to a significant degree. It is also difficult to quantify the degree to which time invested in mentorship may result in future time saved in optimizing productivity and effectiveness at work.

\section{DISCUSSION}

Our systematic review identified 20 separate articles describing 19 mentorship programs for female physicians. While these programs were diverse in nature and scope, several themes emerged. Overall, these programs were primarily focused on junior faculty and medical trainees. It is important to remember that the academic pipeline is leaky across the career trajectory, and while investment in trainees and junior faculty is important, mid-career faculty can also benefit from mentorship. We found no article that described programs specifically aimed at mid-career or senior faculty, and this represents an important area for future research and development.

The dyad model of mentorship was the most commonly used model in the mentorship programs described in the articles we found. This is consistent with a previous systematic review, which described mentorship programs for physicians as a whole in academic medicine. ${ }^{32}$ This previous review also found that peer/facilitated peer mentoring was the second most 
common model of mentorship reported in the literature, which is consistent with our results. ${ }^{32}$ As a lack of senior female mentors is often cited as one possible barrier to mentorship for women, the reliance on dyad mentoring was somewhat surprising, although only four of the ten dyad mentoring programs relied solely on female mentors. Given that all the programs were highly rated regardless of the gender of the mentor, it begs the question of the importance of gender concordance between mentor/mentee pairs. Additionally, while subsets of female faculty do value gender concordance in the mentorship, overall gender concordance was rated lower in importance and preference than other mentor characteristics such as institution, department, and career interests by female academic medical faculty. ${ }^{33}$ As our results showed no detriment to participant satisfaction in gender discordant pairs, academic institutions should view these findings as a justification to expand mentorship programs for women even if senior female mentors are lacking at their center.

We observed some common limitations across the studies included in this review. Several of the articles described additional programs beyond mentorship that were offered to female physicians. This makes it difficult to isolate the impact of mentorship as the outcome data was generally presented for the complete program. Additionally, the lack of a control group in these papers limits the ability to assess for concurrent cultural changes within these institutions that may have facilitated the advancement of women. Also, the majority of these programs limited their evaluations to subjective measures of satisfaction among participants. This makes it more difficult to judge the true impact of these programs on the careers of women in academic medicine. Importantly, however, the eight programs that reported objective outcomes showed improvements in their metrics. This suggests that the benefits of mentorship are real and future work should aim to evaluate objective and long-term outcomes.

The limited discussion of the cost of these programs in terms of both money and faculty time makes it difficult for other academic centers to assess the degree of investment needed to start and continue these sorts of mentorship programs. Moreover, few of the articles reported on barriers or disadvantages that they had encountered, which also limits future programs' abilities to learn from previous mistakes. Future literature should make an effort to report cost in terms of both dollars and faculty time as well as difficulties they encounter. This will ensure that programs can adequately plan for the investment these programs require and learn from each other mistakes going forward.

We limited our review to programs offered within the USA, which we did because the academic medical structure and training programs are unique in the USA compared to other countries; however, this may limit the international generalizability of our results. It is also possible that data exist which meets our inclusion criteria, but that we were not able to include when authors did not stratify results by gender.

\section{CONCLUSION}

A range of successful mentorship programs for women in academic medicine exists in the literature. The traditional dyad model of mentorship remains most common, though, increasingly, peer mentorship programs are emerging. Mentorship programs for women are met with high satisfaction and have been shown to improve the promotion and retention of women faculty. Furthermore, no clear best practices for mentorship emerged in the literature. Institutions, therefore, can individualize their mentorship programs and models to available resources and goals.

Our results also demonstrate that gender concordance is, by no means, a prerequisite for effective mentorship of women in academic medicine, and therefore, a dearth of senior female mentors should not limit the development of these programs. A lack of women in leadership positions has negative implications for an institution's provision of healthcare and educational objectives, ${ }^{34}$ and academic centers which overlook the impact of the leaky pipeline do a disservice to their patients and trainees. Overall, our results demonstrate the importance of further development of these programs in academic centers nationally, to more effectively enhance both the number and success of women in all points of the career spectrum.

Corresponding Author: Amy H. Farkas, MD, MS; Milwaukee VA Medical Center, Milwaukee, WI, USA (e-mail: ahfarkas@mcw.edu).

\section{Compliance with Ethical Standards:}

Conflict of Interest: The authors declare that they do not have a conflict of interest.

\section{REFERENCES}

1. Lautenberge D, Dandar VM, Raezer CL, Sloane RA. The State of Women in Academic Medicine: The Pipeline and Pathways to Leadership. In: Association of American Medical Colleges; 2014.

2. Jena AB, Olenski AR, Blumenthal DM. Sex differences in physician salary in US Public Medical Schools. JAMA Intern Med. 2016;176(9):1294-1304.

3. Morgan AU, Chaiyachati KH, Weissman GE, Liao JM. eliminating gender-based bias in academic medicine: more than naming the "Elephant in the Room". J Gen Intern Med. 2018.

4. Sambunjak D, Straus SE, Marusic A. Mentoring in academic medicine: a systematic review. JAMA. 2006;296(9):1103-1115.

5. Osborn EH, Ernster VL, Martin JB. Women's attitudes toward careers in academic medicine at the University of California, San Francisco. Acad Med. 1992;67(1):59-62.

6. Caniano DA, Sonnino RE, Paolo AM. Keys to career satisfaction: insights from a survey of women pediatric surgeons. J Pediatr Surg. 2004;39(6):984-990.

7. Palepu A, Friedman RH, Barnett RC, et al. Junior faculty members' mentoring relationships and their professional development in U.S. medical schools. Acad Med. 1998;73(3):318-323.

8. Wise MR, Shapiro $\mathbf{H}$, Bodley $\mathbf{J}$, et al. Factors affecting academic promotion in obstetrics and gynaecology in Canada. J Obstet Gynaecol Can. 2004;26(2):127-136.

9. Butkus R, Serchen J, Moyer DV, et al. Achieving gender equity in physician compensation and career advancement: a position paper of the american college of physicians. Ann Intern Med. 2018.

10. Liberati A, Altman DG, Tetzlaff $\mathbf{J}$, et al. The PRISMA statement for reporting systematic reviews and meta-analyses of studies that evaluate 
health care interventions: explanation and elaboration. Ann Intern Med. 2009; 151(4):W65-94.

11. Beech BM, Calles-Escandon J, Hairston KG, Langdon SE, LathamSadler BA, Bell RA. Mentoring programs for underrepresented minority faculty in academic medical centers: a systematic review of the literature. Acad Med. 2013;88(4):541-549.

12. Kosoko-Lasaki O, Sonnino RE, Voytko ML. Mentoring for women and underrepresented minority faculty and students: experience at two institutions of higher education. J Natl Med Assoc. 2006;98(9):14491459.

13. Files JA, Blair JE, et al. Facilitated peer mentorship: a pilot program for academic advancement of female medical faculty. J Women's Health (2002). 2008;17(6):1009-1015.

14. Varkey $\mathbf{P}$, Jatoi A, et al. The positive impact of a facilitated peer mentoring program on academic skills of women faculty. BMC Med Educ. 2012;12:14.

15. Mayer AP, Blair JE, et al. Long-term follow-up of a facilitated peer mentoring program. Med Teach. 2014;36(3):260-266.

16. Wingard DL, Garman KA, Reznik V. Facilitating faculty success: outcomes and cost benefit of the UCSD National Center of Leadership in Academic Medicine. Acad Med. 2004;79(10 Suppl):S9-11.

17. Seritan AL, Bhangoo R, et al. Society for women in academic psychiatry: a peer mentoring approach. Acad Psychiatry. 2007;31(5):363-366.

18. Mayer AP, Files JA, et al. The academic quilting bee. J Gen Intern Med. 2009;24(3):427-429.

19. Illes J, Glover GH, et al. A model for faculty mentoring in academic radiology. Acad Radiol. 2000;7(9):717-724; discussion 725-716.

20. Von Feldt JM, Bristol M, et al. The brief CV review session: one component of a mosaic of mentorship for women in academic medicine. $J$ Natl Med Assoc. 2009;101(9):873-880.

21. Butch L. Mentorship program designed to advance women in academic surgery. Bull Am Coll Surg. 2009;94(10):6-10.

22. Levy AS, Pyke G, et al. Mentoring in pediatric oncology: a report from the Children's Oncology Group Young Investigator Committee. J Pediatr Hematol Oncol. 2013;35(6):456-461.

23. Blood EA, Trent M, et al. Leadership in adolescent health: developing the next generation of maternal child health leaders through mentorship. Matern Child Health J. 2015;19(2):308-313.

24. Erlich DR, Cohen-Osher MB, Goodell KH. 'We rise by lifting others': peer support and professional development for women in academic medicine. Educ Prim Care. 2017;1-4.

25. Bauman MD, Howell LP, Villablanca AC. The Women in Medicine and Health Science program: an innovative initiative to support female faculty at the University of California Davis School of Medicine. Acad Med. 2014;89(11):1462-1466.

26. Lin SY, Francis HW, et al. Faculty diversity and inclusion program outcomes at an academic otolaryngology department. Laryngoscope. 2016;126(2):352-356.

27. Ladd LM, Bonaminio DN, Gonda AS, et al. A mentorship and networking group for women in radiology. J Am Coll Radiol. 2017;14(7):987-990.

28. Welch JL, Jimenez HL, et al. The women in emergency medicine mentoring program: an innovative approach to mentoring. J Grad Med Educ. 2012;4(3):362-366.

29. Khan S, Ferrada P. Empowering surgical residents as mentors: a pilot program for female medical students. Am Surg. 2016;82(11):313-314.

30. DeFilippis E, Cowell E, et al. Innovative mentoring for female medical students. Clin Teach. 2016;13(5):381-382.

31. Bhatia K, Takayesu JK, et al. An innovative educational and mentorship program for emergency medicine women residents to enhance academic development and retention. CJEM. 2015;17(6):685-688
32. Kashiwagi DT, Varkey P, Cook DA. Mentoring programs for physicians in academic medicine: a systematic review. Acad Med. 2013;88(7):10291037.

33. Carapinha R, Ortiz-Walters R, McCracken CM, Hill EV, Reede JY Variability in women faculty's preferences regarding mentor similarity: a multi-institution study in academic medicine. Acad Med. 2016;91(8):1108-1118

34. Bickel J, Wara D, Atkinson BF, Cohen LS, Dunn M, Hostler S, Johnson TR, Morahan P, Rubenstein AH, Sheldon GF, Stokes E; Association of American Medical Colleges Project Implementation Committee. Increasing women's leadership in academic medicine: report of the AAMC Project Implementation Committee. Academic Medicine: journal of the Association of American Medical College. 2002;77(10):1043-61.

\section{APPENDIX. PUBMED SEARCH STRATEGY}

("Mentoring"[Mesh] OR "Mentors"[Mesh] OR mentor*[title] OR mentee*[title] OR mentor*[ot] OR mentee*[ot]) AND (“Academic Medical Centers"[MeSH:NoExp] OR "Education, Medical"[Mesh] OR "Faculty, Medical"[Mesh] OR "Foreign Medical Graduates"[Mesh] OR "Hospitals, Teaching"'[Mesh] OR "Schools, Medical”"[Mesh] OR "Students, Medical"'[Mesh] OR foreign medical graduate*[tiab] OR medical faculty[tiab] OR medical school*[tiab] OR medical student*[tiab] OR foreign medical graduate*[ot] OR medical faculty[ot] OR medical school*[ot] OR medical student*[ot] OR ((“Faculty”[Mesh:NoExp] OR "Internship and Residency"[Mesh] OR "Universities"[Mesh] OR academic*[tiab] OR facult*[tiab] OR intern[tiab] OR interns[tiab] OR professor*[tiab] OR residents*[tiab] OR universit*[tiab] OR academic*[ot] OR facult*[ot] OR intern[ot] OR interns[ot] OR professor*[ot] OR residents*[ot] OR universit*[ot]) AND ("Medicine"[Mesh] OR "Physicians"[Mesh] OR hospitalist*[tiab] OR immunology[tiab] OR medical*[tiab] OR medicine*[tiab] OR nephrology[tiab] OR pediatric[tiab] OR physician*[tiab] OR radiology[tiab] OR rheumatology[tiab] OR surgery[tiab] OR hospitalist*[ot] OR immunology[ot] OR medical*[ot] OR medicine*[ot] OR nephrology[ot] OR pediatric[ot] OR physician*[ot] OR radiology[ot] OR rheumatology[ot] OR surgery[ot])))

This paper was presented at the Society of General Internal Medicine meeting as an oral presentation in April 2018.

Publisher's Note Springer Nature remains neutral with regard to jurisdictional claims in published maps and institutional affiliations. 